\title{
Quality of life and time since diagnosis of Diabetes Mellitusamong the elderly
}

\author{
Luciano Ramos de Lima, ${ }^{12}$ \\ Silvana Schwerz Funghetto, ${ }^{1,2}$ \\ Cris Renata Grou Volpe ${ }^{2}$ \\ Walterlânia Silva Santos, ${ }^{2,3}$ \\ Mani Indiana Funez, ${ }^{1,2}$ \\ Marina Morato Stival ${ }^{2}$
}

Abstract

Objectives: To evaluate the quality of life of the elderly with Diabetes Mellitus and to relate the time since diagnosis of diabetes with the quality of life of elderly persons receiving care at a basic health unit. Method: A cross-sectional quantitative study carried out in a Basic Health Unit with 196 elderly persons. For data collection, three instruments were used: one structured (sociodemographic and clinical variables) and the Whoqol-bref and Whoqol-old, with scores ranging from 0 to 100. Descriptive statistical analysis, Student's T-test and Pearson's correlation were performed. Results: Of the 196 diabetic patients, the majority were male $(54.6 \%)$ with a mean age of $67.5( \pm 6.5)$ years. The mean time since diagnosis of Diabetes Mellitus was 9.1 years. The domains of the Whoqol-bref with the highest scores, indicating better quality of life, were Social Relations and Psychological, while a worse quality of life was observed in Environment. The facets of the Whoqol-old with the best scores were: Intimacy and Past, Present and Future Activities, and the worst was Death and Dying. The domains associated with one another were Physical and Psychological, Physical and Social Relations, and Psychological and Environmental. The associated aspects were Past, Present and Future Activities and Social Participation. Elderly persons with more than ten years of Diabetes Mellitus had worse quality of life scores in Physical ( $p=0.001)$, Social relations ( $p=0.002)$, and in the Autonomy ( $p=0.0012)$, Social Participation $(p=0.041)$ and Death and Dying $(p=0.001)$ facets. Conclusion: The time of diagnosis of Diabetes Mellitus was negatively associated with the quality of life of the elderly, with worse scores in most domains and facets of the Whoqol.

\footnotetext{
Universidade de Brasília, Faculdade de Ceilândia, Programa de Pós-graduação Ciências e Tecnologias em Saúde. Brasília, Distrito Federal, Brasil.

2 Universidade de Brasília, Faculdade de Ceilândia, Curso de Graduação em Enfermagem. Brasília, Distrito Federal, Brasil.

3 Universidade de Brasília, Faculdade de Ciências da Saúde, Programa de Pós-graduação em Enfermagem. Brasília, Distrito Federal, Brasil.
}

Correspondence

Marina Morato Stival

marinamorato@unb.br
Keywords: Quality of Life. Elderly. Diabetes Mellitus. Primary Health Care. Geriatric Nursing. 


\section{INTRODUCTION}

Diabetes Mellitus (DM) is a chronic nontransmissible metabolic disease of multifactorial origin. It is characterized by the permanent elevation of glycemic levels due to the absence or incapacity of insulin to perform its physiological function, generating a series of complications and dysfunctions of the essential organs. It is considered a worldwide epidemic and a public health problem, with growing global prevalence. World Health Organization estimates of DM suggest that the disease accounted for 1.4 million deaths in 2011. They also state that there will be a $69 \%$ increase in the number of adults with DM in developing countries and 20\% in developed countries between 2010 and 2030. By 2025 , the expectation is that 350 million people will be affected by the disease, of whom 18.5 million will live in Brazil ${ }^{1,2}$.

Research in Brazil has found incidences of $\mathrm{D} M$ among the elderly ranging from 18.6 to $23.5 \%$. The increase in the life expectancy of the elderly, when associated with inadequate living habits, results in a higher incidence of chronic diseases, notably $D M$, in this population ${ }^{3-5}$.

As well as being expensive to control and treat, $\mathrm{D} M$ also has a deleterious effect on the quality of life (QoL) of the elderly. Several factors can influence the QoL of such patients with $\mathrm{D} M$, such as insulin use, age, gender, income, education, complications of the disease, psychological factors, knowledge of the disease and type of health care, among others $^{1,6-11}$. It is also evident that better glycemic control is associated with improved QoL. Constant hyperglycemia and long-term DM are factors associated with complications, which can affect about $50 \%$ of the patients and occur around ten years after the diagnosis of the disease $\mathrm{i}^{1,12}$.

QoL in this context is defined broadly and with different interpretations. In the present study we applied the definition of the World Health Organization (WHO) which defines QOL as the perception of the individual of their position in life, in the context of the culture and value systems in which they live in relation to their goals, expectations, standards and concerns ${ }^{13,14}$.
$\mathrm{D} M$ is a progressive disease in which the state of health of affected individuals, especially the elderly, tends to deteriorate over time, especially after ten years of living with the disease, when the complications derived from poor glycemic control, which may negatively affect their QoL, can appear ${ }^{4,9,11}$. $\mathrm{D} M$ has a significant physical and emotional impact, culminating in the reduction of the autonomy and self-confidence of these individuals, altering their self-perception so that they see themselves as unable to fulfill their objectives, thus reducing their QoL ${ }^{1,4,12,14}$. The theme of QoL in elderly patients with $\mathrm{D} M$ has already been investigated in many studies ${ }^{6-12}$, but there is still a lack of research that compare the QoL of the elderly after living with the disease for a decade. The present study therefore proposes to associate the duration of $\mathrm{D} M$ and the QoL of these patients, and the interaction between the domains of QoL, aiming to guide future care of diabetes among the elderly, mainly in the primary health care offered to these individuals.

In view of the above, the present study aimed to evaluate the quality of life of the elderly with Diabetes Mellitus (DM) and to relate the time since the diagnosis of $\mathrm{D} M$ to the quality of life of elderly persons receiving care in a basic health unit of the Distrito Federal (the Federal District) in Brazil. The study also sought to identify a relationship between the domains and facets of the instruments used to measure quality.

\section{METHOD}

A quantitative, descriptive, exploratory and crosssectional study was carried out in a Basic Health Unit (BHU) of the Distrito Federal, Brazil.

The study population consisted of elderly individuals who met the following inclusion criteria: age 60 or older and enrolled in the Diabetic Group of the BHU. Approximately 500 elderly people were enrolled in this group and considering a margin of error of $5 \%$ and a confidence level of $95 \%$, a representative sample of 218 elderly people was calculated. All the elderly persons were invited to participate in the study, which resulted in a convenience sample of 202 elderly individuals who agreed to participate in the research. 
The exclusion criterion considered was the medical diagnosis of mental and psychiatric disorders that would prevent the elderly from answering the questions of the instruments. Of the 202 elderly persons, six who met the exclusion criterion were excluded from the study, giving a final sample of 196 individuals.

The elderly were initially approached in the BHU during the Diabetics Group meetings and were informed of the objective of the research and invited to participate in the study. Data collection took place after the signing of a Free and Informed Consent Form between August and December 2016.

Three instruments were used for data collection: a structured questionnaire, composed of closed questions, aimed at identifying the socioeconomic and demographic profile of the elderly (age, gender, income, marital status, schooling and occupation), life habits (smoking, sedentary lifestyle and dietary control) and clinical conditions (time since diagnosis of Diabetes Mellitus, insulin use, visual changes and self-reported foot injuries) with the objective of characterizing the population involved. The second instrument was the World Health Organization Quality of Life - BREF (WHOQOL-BREF) and the third was the World Health Organization Quality of Life Assessment for Older Adults (WHOQOLOLD), both validated for Brazil, which were applied by the researchers to avoid influencing the responses of the individual. The instruments were applied in a single meeting with each elderly person, in privacy. The reading of the questionnaires was carried out together with the elderly persons and their answers were recorded by the researchers, who were previously trained for this task.

The WHOQOL-BREF, considered a generic instrument, consists of four domains: Physical, Psychological, Social Relationships and Environment ${ }^{5}$. The WHOQOL-OLD, a specific instrument for the elderly, is composed of six facets: Sensory Abilities, Autonomy, Past, Present and Future Activities, Social Participation, Death and Dying and Intimacy. The scores of both instruments vary from 0 to 100 , with the highest value corresponding to the best quality of life ${ }^{16}$.
The interviews underwent revision and codification. The data collected were processed into a database by two people, using the double entry system. Inconsistencies between the two databases, if any, were corrected following consultation with the original interview. The questionnaires were consolidated with the respective syntaxes. The WHOQOL-BREF domains and WHOQOL-OLD facets were analyzed separately.

The Cronbach's alpha coefficient was calculated to evaluate the homogeneity of the items of the instruments. To analyze the normality of the variables the Kolmogorov-Smirnov test was applied. The Student's t-test was used to verify the differences between the means of the QoL measures. For the analysis of the relationship between the different domains and facets analyzed, the Pearson correlation was used, observing the amplitude of the relationship. This measure ranges from -1 (perfect negative correlation) to +1 (perfect positive correlation), as well as 0 (absence of correlation). Correlations greater than 0.50 (moderate and strong correlation) were considered. The significance level considered was $p \leq 0.05$.

The project was approved by the Research Ethics Committee of the Health Department of the Distrito Federal under approval $n^{\circ} 251.361$ and CAEE $n^{\circ}$ 14557613.1.0000.5553.

\section{RESULTS}

A total of 196 diabetic patients were interviewed, most of whom were male, aged $67.5( \pm 6.5)$ years, single, with one to five years of schooling, an income of up to one minimum wage (MW) and were retirees (Table 1).

The average time of diabetes mellitus $(\mathrm{D} M)$ among the patients was $9.1( \pm 6.2)$ years (Minimum: 1 year, Maximum: 40 years). Most did not use insulin and were not smokers or sedentary. The majority reported not having control diets, said they suffered from visual disorders and did not have foot injuries (Table 1). 
Table 1. Sociodemographic and clinical variables of elderly persons with Diabetes Mellitus (N=196). Brasília, DF, 2017.

\begin{tabular}{|c|c|c|c|}
\hline Variables & $\mathrm{n}(\%)$ & Variables & $\mathrm{n}(\%)$ \\
\hline Gender & & Uses insulin & \\
\hline Female & $89(45.4)$ & Yes & $64(32.7)$ \\
\hline Male & $107(54.6)$ & No & $132(67.3)$ \\
\hline Age (years) & & Smoking & \\
\hline $60-70$ & $143(73.0)$ & Yes & $26(13.3)$ \\
\hline $71-80$ & $42(21.4)$ & No & $170(86.7)$ \\
\hline$>80$ & $11(5.6)$ & & \\
\hline Marital status & & Alcohol abuse & \\
\hline Unmarried & $80(40.8)$ & Yes & $18(9.2)$ \\
\hline Married & $58(29.6)$ & No & $178(90.8)$ \\
\hline Widower & $24(12.2)$ & & \\
\hline Divorced & $34(17.4)$ & & \\
\hline Education & & Physical activity & \\
\hline Illiterate & $38(19.3)$ & Yes & $84(42.9)$ \\
\hline $1-5$ years & $144(73.5)$ & No & $112(57.1)$ \\
\hline 6-9 years & $13(6.7)$ & & \\
\hline$>9$ years & $1(0.5)$ & & \\
\hline Monthly Income (minimum wage) & & Dietary Control & \\
\hline up to 1 & $120(61.2)$ & Yes & $67(34.2)$ \\
\hline between 1 and 3 & 57 (29.1) & No & $129(65.8)$ \\
\hline$>4$ & $19(9.7)$ & & \\
\hline Occupation & & Visual disorders & \\
\hline Unemployed & $41(20.9)$ & Yes & $146(74.5)$ \\
\hline Retired & $124(63.3)$ & No & $50(25.5)$ \\
\hline \multirow[t]{3}{*}{ Others } & $31(15.8)$ & Foot injuries & \\
\hline & & Yes & $34(17.3)$ \\
\hline & & No & $162(82.7)$ \\
\hline
\end{tabular}

In the evaluation of the QOL of the elderly with $\mathrm{D} M$ it was observed that the Whoqol-bref domains with the highest scores were: Social relationships $(\mathrm{M}=66.70 \pm 20.95)$ and Psychological $(\mathrm{M}=60.18 \pm 14.89)$, while the lowest scoring domain was Environment $(\mathrm{M}=55.89 \pm 15.77)$. The Whoqol-old facets with the highest scores were: Intimacy $(\mathrm{M}=69.51 \pm 23.48)$ and Past, Present and Future Activities ( $\mathrm{M}=66.10 \pm 18.22)$, while the lowest scoring was Death and Dying $(\mathrm{M}=55.58 \pm 31.97)$ (Table 2).

The evaluation of the internal consistency of the instruments for the evaluation of QoL using
Cronbach's Alpha Coefficient revealed homogeneity of the domains and facets (Table 2).

Table 3 shows the relationship between the domains and facets analyzed. The domains with the greatest strength of association were Physical and Psychological $(\mathrm{r}=0.53)$, Physical and Social Relationships $(\mathrm{r}=0.54)$ and Psychological and Environmental $(\mathrm{r}=0.52)$. In the relationships between the facets, many significant associations were evident $(p<0.01)$, but those most closely associated with one another and with moderate correlation were Past, Present and Future Activities and Social Participation ( $\mathrm{r}=0.57)$ (Table 3). 
Table 2. Cronbach's reliability measures of the Whoqol-bref domains and Whoqol-old facets of elderly persons with Diabetes Mellitus (N=196). Brasília, DF, 2017.

\begin{tabular}{llll}
\hline WHOQOL-Bref Domains & $\mathrm{M}( \pm \mathrm{sd})$ & Mín./Max. & Cronbach’s Alpha \\
\hline Physical & $58.47( \pm 14.36)$ & $25.00 / 96.43$ & 0.731 \\
Psychological & $60.18( \pm 14.89)$ & $20.83 / 91.67$ & 0.716 \\
Social Relationships & $66.7( \pm 20.95)$ & $8.33 / 100.00$ & 0.739 \\
Environment & $55.89( \pm 15.77)$ & $12.5 / 93.75$ & 0.750 \\
\hline WHOQOL-Old Facets & & & \\
\hline Sensory abilities & $63.58( \pm 23.66)$ & $0.00 / 100.00$ & 0.746 \\
Autonomy & $57.97( \pm 18.08)$ & $6.25 / 100.00$ & 0.777 \\
Past. Present and future activities & $66.1( \pm 18.22)$ & $6.25 / 100.00$ & 0.757 \\
Social participation & $60.14( \pm 19.27)$ & $6.25 / 100.00$ & 0.765 \\
Death and dying & $55.58( \pm 31.97)$ & $0.00 / 100.00$ & 0.782 \\
Intimacy & $69.51( \pm 23.48)$ & $0.00 / 100.00$ & 0.781 \\
\hline
\end{tabular}

Min/Max: minimum/maximum.

Table 3. Matrix of correlation between Whoqol-bref domains and Whoqol-old facets of elderly persons with Diabetes Mellitus (N=196). Brasília, DF, 2017.

\begin{tabular}{llllll}
\hline WHOQOL Bref Domains & 1 & 2 & 3 & 4 & \\
\hline 1. Physical & 1.00 & & & & \\
2. Psychological & $0.53^{* *}$ & 1.00 & & & \\
3. Social relationships & $0.54^{* *}$ & $0.50^{* *}$ & 1.00 & & \\
4. Environment & $0.40^{* *}$ & $0.52^{* *}$ & $0.46^{* *}$ & 1.00 & \\
\hline WHOQOL Old Facets & 1 & 2 & 3 & 4 & 5 \\
\hline 1. Sensory abilities & 1.00 & & & & \\
2. Autonomy & $0.21^{* *}$ & 1.00 & & & \\
3. Past. present and future activities & 0.09 & $0.46^{* *}$ & 1.00 & & \\
4. Social participation & $0.23^{* *}$ & $0.40^{* *}$ & $0.57^{* *}$ & 1.00 & \\
5. Death and dying & $0.20^{* *}$ & 0.11 & -0.02 & $0.15^{*}$ & 1.00 \\
6. Intimacy & -0.05 & 0.06 & $0.33^{* *}$ & $018^{* *}$ & -0.09 \\
\hline
\end{tabular}

$* * p<0.01 ; * p<0.05$ - Pearson's Correlation.

The results shown in Figure 1 illustrate the associations between QoL and time since diagnosis of Diabetes Mellitus (DM). The domains with a significant statistical difference between the scores obtained based on time with $\mathrm{D} M$ were Physical $(p=0.001)$ and Social Relationships $(p=0.002)$, with elderly persons who had been diagnosed with $\mathrm{D} M$ more than ten years ago having worse QoL scores in these domains than elderly persons who had had the disease for less than ten years. The Physical domain had the lowest mean (57.3), while the Social Relationships domain exhibited the greatest variation between the two groups (13.3), with the mean scores higher in those with less than ten years of $\mathrm{D} M$.

In the comparison of QoL assessed by the Whoqolold among the elderly based on the time since diagnosis with DM, the facets Autonomy ( $p=0.012)$, Social Participation $(p=0.041)$ and Death and Dying $(p=0.001)$ revealed statistical differences between the scores of the two groups, as shown in Figure 2. The elderly persons with more than ten years since $\mathrm{D} M$ diagnosis had lower QoL scores in these facets. The Death and Dying facet presented the greatest discrepancy between the values based on the duration of $\mathrm{D} M$. 


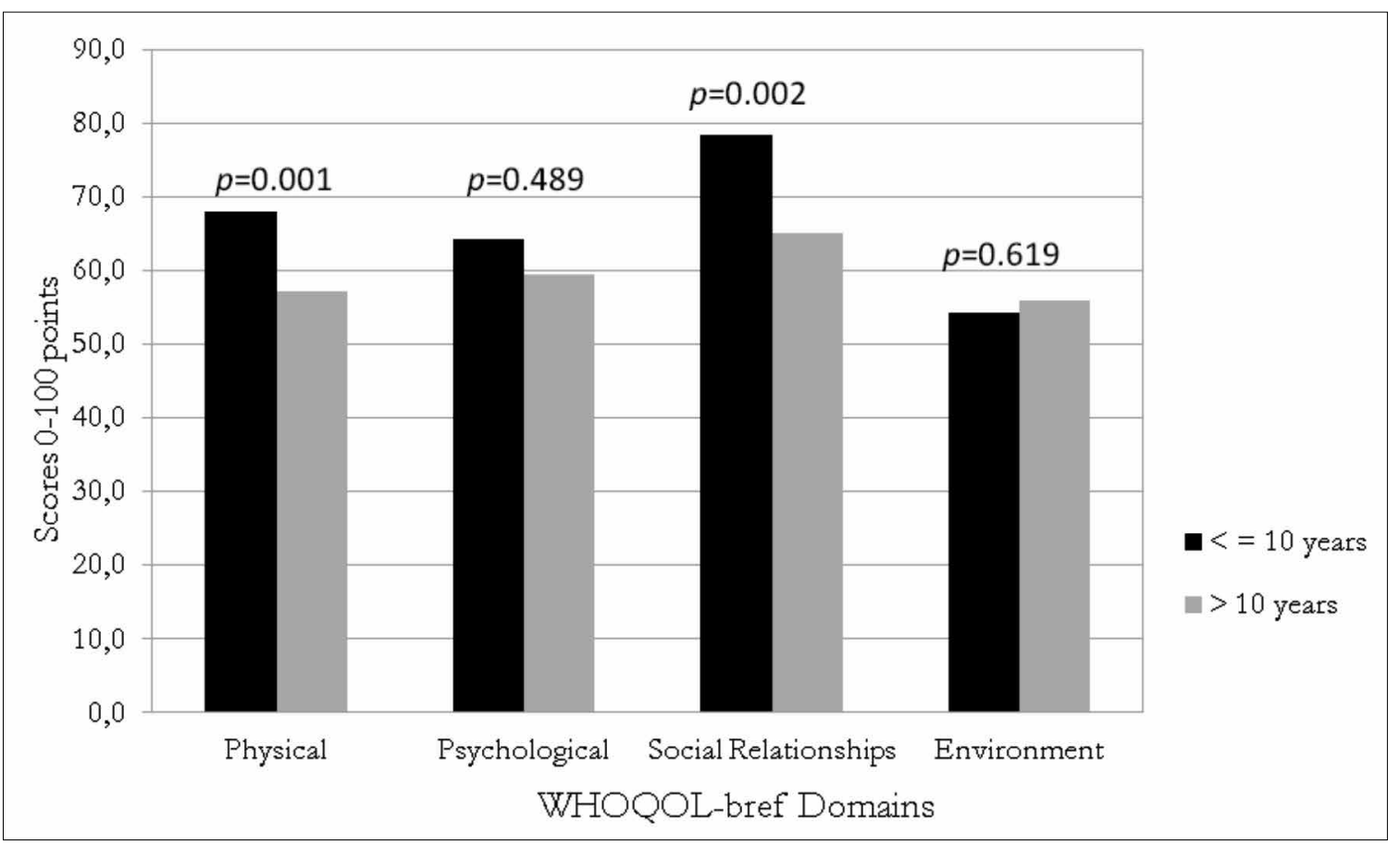

Figure 1. Means of elderly persons based on time with Diabetes Mellitus (N=196). Brasília, DF, 2017.

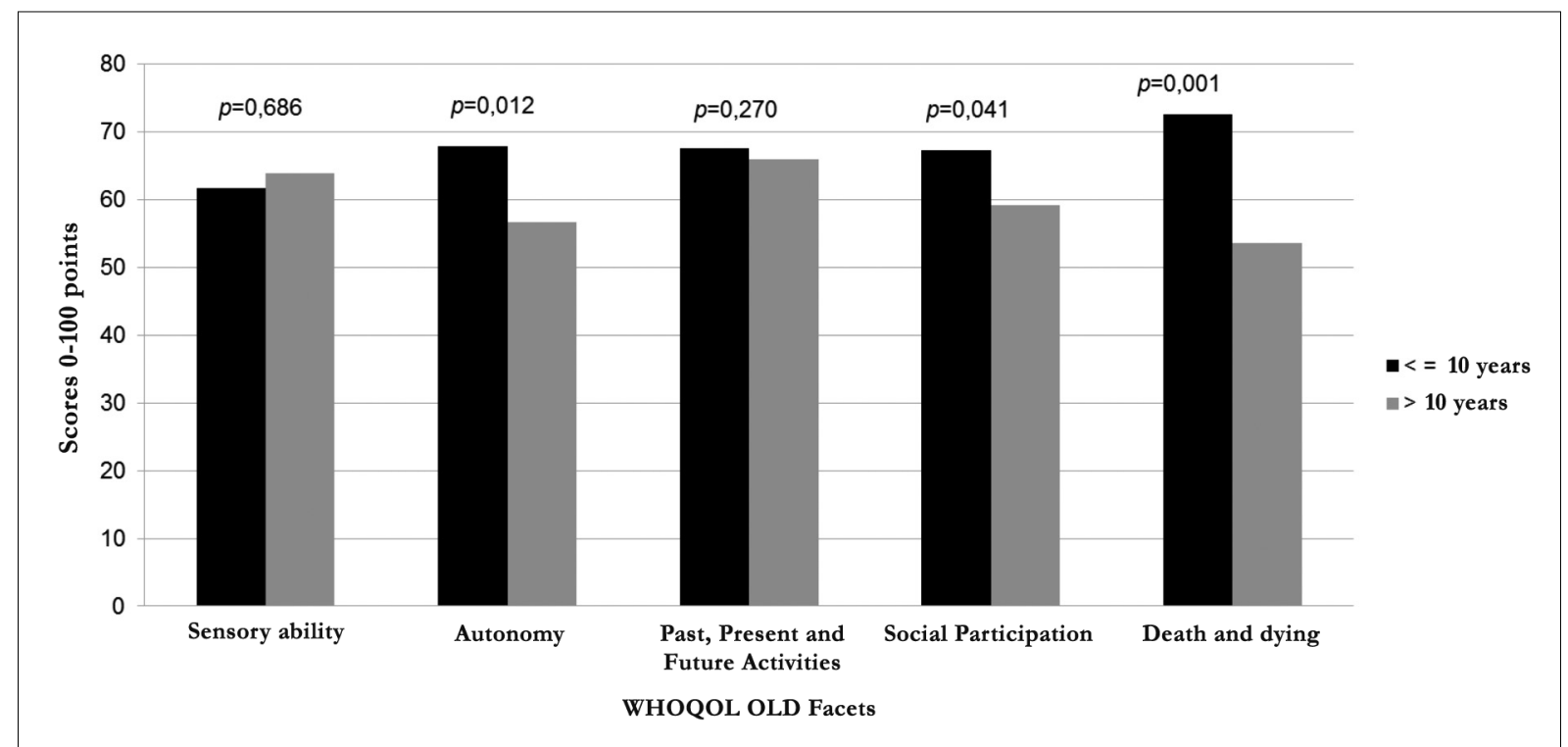

Figure 2. Average of Whoqol-old facets of elderly persons according to the time of Diabetes Mellitus (N=196). Brasilia, DF, 2017.

\section{DISCUSSION}

The sociodemographic characterization revealed a predominance of male elderly persons, aged between 60 and 70 years, who were single and had little schooling, a low income and were retirees. Similar results were found in other studies in relation to age, schooling, income and retirement status ${ }^{3,8-10}$.
In contrast, other studies found a predominance of females and married individuals ${ }^{3,7-9}$.

Regarding life habits and time of $\mathrm{D} M$, the elderly had an average of less than 10 years with $\mathrm{D} M$, were sedentary, non-smokers and abused alcohol, but said they did not have controlled diets. The majority reported visual disorders and had no foot injuries. 
The time since diagnosis found in the present study corroborated with the result of other studies carried out with elderly persons in Piaui ${ }^{8}$ and Fortaleza ${ }^{10}$. Inappropriate behavior were also found in other studies ${ }^{910,12}$. The importance of healthy living habits for both the physical and mental health of the elderly, resulting in a better quality of life, should be emphasized. Therefore, intervention processes are recommended for health professionals who perform preventive, educational and health care activities for the elderly?

The domains of the Whoqol-bref with the highest QoL scores, and consequently the highest satisfaction of the elderly persons in relation to their health, were Social Relationships followed by Psychological. This finding was similar to other studies which also found the highest mean scores in the Social Relationships domain ${ }^{11,17-19}$.

Despite their illness, the elderly persons felt socially supported and said that they had good social relationships. This may be related to the activities carried out by the nurses of the health unit, who organized meetings, trips and opportunities for social interaction with friends in order to promote the participation of the elderly in social groups. These activities are provided for the elderly persons who participated in the Diabetes Group of UBS, thus demonstrating the satisfaction of the elderly with their presence in this group.

The Psychological domain assesses issues related to positive and negative feelings, concentration, self-esteem, appearance, spirituality and personal beliefs. Although the study revealed higher scores in the Psychological domain, it is known that feelings are part of the process of adaptation of the individual to chronic disease, which can compromise their psychological state, especially as the elderly are told from the beginning of treatment that $\mathrm{D} M$ has no cure but can only be controlled. In addition, warnings about possible complications can result in negative feelings and expectations for the future, which exacerbates this aspect in the evaluation of $\mathrm{QoL}^{20}$.

In contrast, a lower score was observed in the Environment domain, illustrating the low satisfaction of this population group with the environment in which they live, a result similar to that found in another study with elderly people with $\mathrm{D} M$ in
Uberaba (Minas Gerais) ${ }^{7}$ and with elderly people with $\mathrm{D} M$ in the rural part of $\mathrm{Bahia}{ }^{11}$. Another study conducted with 277 elderly people in the Distrito Federal also resulted in low QoL scores in the Environment domain, which may be related to the fact that the elderly do not feel safe and protected in their home environment ${ }^{9}$. Good housing conditions, physical security, financial resources, transportation, and the acquisition of consumer goods, among other factors, may be associated with improved quality of life $\mathrm{f}^{11}$.

The Whoqol-old facets with the best scores were: Intimacy and Past, Present and Future Activities, while the lowest score was in Death and Dying. It was notable that the standard deviations in these facets were high, revealing the significant variation in the responses of the elderly.

The Intimacy facet evaluates the ability of the elderly persons to relate to other people ${ }^{16}$. The low number of widowed and divorced elderly persons may have affected this finding, as we believe that the loss of a spouse or partner can influence living with another person and intimate relationships. The elderly were also satisfied with their achievements throughout life and what they still desire. In contrast, a difficulty in accepting death in some elderly was observed in this study.

A study of 51 elderly people with DM in Campina Grande (São Paulo) also showed better QoL scores in the Past, Present and Future Activities, emphasizing that the elderly persons have aspirations that may not have been achieved and that encourage feelings of hope, although a lower QoL was observed in the Sensory Ability domain ${ }^{21}$.

In the analysis of the relationships between the domains, those with a good correlation were the Physical domain with Social Relationships and the Psychological domain with Environment. It is understood that good physical health benefits social relationships. $\mathrm{D} M$ predisposes the elderly to acute and chronic complications which can make them feel physically frail. It is worth mentioning that the majority of participants in this study were sedentary, did not have a controlled diet and reported visual disorders, which may negatively impact physical aspects and consequently affect their social relations. 
The relationship between Psychology and the Environment can be explained by the fact that the region where the study was carried out has high levels of violence, and that the majority of the elderly interviewed had an income of up to one minimum wage, living in areas with precarious, unsafe environments with unpaved roads, where they do not leave the house alone and are more susceptible to social isolation and depression.

In terms of the correlation between facets, there was a good correlation between Past, Present and Future Activities and Social Participation. This result shows that the satisfaction of the elderly with their life achievements and future expectations is closely linked to their social participation. This fact may be related to the chronicity of the disease and the complications that interfere in the independence of elderly persons with $\mathrm{D} M$, limiting the accomplishment of pleasurable activities, and thus bringing insecurity about the future. It is important that politicians and health professionals are aware that people living with a chronic condition, especially $\mathrm{D} M$, suffer not only the burden of disease but also a social burden, as social isolation can be highly detrimental to overall well-being ${ }^{22}$.

In the present study, the time since the diagnosis of diabetes was found to be a highly influential variable on QoL. The scores of most of the domains and facets of the QoL instruments declined as time spent with $\mathrm{D} M$ increased.

The domains which demonstrated a significant statistical difference between scores based on time since diagnosis with $\mathrm{D} M$ were the Physical and Social Relationships, with the elderly persons with more than ten years of $\mathrm{D} M$ diagnosis having lower $\mathrm{QoL}$ scores in these domains than those with less than ten years of illness. The results of the present study corroborate a study conducted in Pakistan with 501 diabetics which found that patients with more than ten years of diabetes had lower scores in all domains, indicating a decrease in QoL as time with $D M$ increaed $^{23}$. Another study identified the impact of $\mathrm{D} M$ duration on QoL when evaluating 201 elderly people in Montes Claros (Minas Gerais), finding that a time since $\mathrm{D} M$ diagnosis of over ten years negatively influenced the QoL of the elderly ${ }^{24}$.
Still in this sense, in comparing QOL as evaluated by the Whoqol-old based on time of diagnosis of $\mathrm{DM}$ it was evident that the Autonomy, Social Participation, and Death and Dying facets presented statistical differences, with elderly persons with more than ten years of diagnosis of $\mathrm{D} M$ having lower QoL scores in these facets.

Autonomy and social participation diminish over the years due to the greater impairment caused by the disease. With more than ten years of illness patients with $\mathrm{D} M$ may have greater physical limitations, intensity of pain and discomfort, with a negative affect on their daily life and even increasing feelings of sadness, social isolation and fear of death. In addition, the loss of autonomy and decision-making power may influence self-esteem and lead to disregard for health, reducing self-care and thus favoring the appearance of chronic complications from the disease ${ }^{25-29}$.

It is noteworthy that in this study $17.3 \%$ of diabetics had foot injuries, which may reflect a decrease in autonomy and social participation as a consequence of decreased mobility associated with vascular or neuropathic pain.

Duration of disease is a relevant variable, as it has an inverse relationship with adherence to treatment. The longer the diagnosis, the lower the prevalence of adherence to treatment of users, and the greater the risk of harm resulting from unsatisfactory metabolic control and, consequently, a deterioration in $\mathrm{QOL}^{29}$.

One of the limitations of the present study was its cross-sectional design, which did not allow the follow-up monitoring of the elderly to identify causal factors, and also the fact that it did not incorporate a control group for comparison. Another limitation was the representativeness of the sample, as the calculated sample size was not achieved.

\section{CONCLUSION}

The present study identified a better QoL in the Social Relationships and Psychological domains and in the Intimacy and Past, Present and Future Activities facets. A worse QoL among the elderly, meanwhile, was observed in the Environment domain and in the Death and Dying facet. 
Regarding the impact of time since diagnosis with $\mathrm{D} M$ on the QoL of these elderly individuals, the results of this study found a worse QoL in the Physical, Psychological and Social Relationships domains and in the Autonomy, Past, Present and Future Activities, Social Participation and Death and Dying facets in elderly persons with more than ten years of $\mathrm{D} M$.
The present study is relevant as it can guide health professionals who work mainly in primary care in the control and prevention of DM complications. Care for such elderly persons should be organized to promote a better QoL as the main problems related to the time since the diagnosis of the disease have been identified.

\section{REFERENCES}

1. Ababio GK, Bosomprah S, Olumide A, Aperkor N, Aimakhu C, Oteng-Yeboah A, et al. Predictors of quality of life in patients with diabetes Mellitus in Two Tertiary Health Institutions in Ghana and Nigeria. Nigerian Postgrad Med J [Internet]. 2017 [acesso em 15 jun. 2017];24(1):48-55. Disponível em: http://www. npmj.org/article.asp?issn $=1117-1936$; year $=2017$; volume $=24$; issue $=1$; spage $=48$; epage $=55$; aulast $=$ Ababio

2. Brasil. Ministério da Saúde, Secretaria de Atenção à Saúde, Departamento de Atenção Básica. Diabetes Mellitus. Brasília, DF: Ministério da Saúde; 2006.

3. Mendes TAB, Goldbaum M, Segri NJ, Barros MBA, Cesar CLG, Carandina L, et al. Diabetes Mellitus: fatores associados à prevalência em idosos, medidas e práticas de controle e uso dos serviços de saúde em São Paulo, Brasil. Cad Saúde Pública. 2011;27(6):1233-43.

4. Silva AB, Engroff P, Sgnaolin V, Ely LS, Gomes I. Prevalência de diabetes mellitus e adesão medicamentosa em idosos da Estratégia Saúde da Família de Porto Alegre/RS. Cad Saúde Coletiva [Internet]. 2016 [acesso em 03 set. 2016];24(3):30831. Disponível em: http://www.scielo.br/pdf/cadsc/ v24n3/1414-462X-cadsc-24-3-308.pdf

5. Iser BPM, Stopa SR, Chueiri OS, Szwarcwald CL, Malta DC, Monteiro HOC, et al. Prevalência de diabetes autorreferido no Brasil: resultados da Pesquisa Nacional de Saúde 2013. Epidemiol Serv Saúde [Internet]. 2015 [acesso em 10 set. 2016];24(2):305-14. Disponível em: http://www.scielo. br/pdf/ress/v24n2/2237-9622-ress-24-02-00305.pdf

6. Tavares DMS, Cortês RM, Dias FA. Qualidade de vida e comorbidades entre os idosos diabéticos. Rev Enferm UERJ [Internet]. 2010 [acesso em 15 Dez. 2016];18(1):97-103. Disponível em: http://www.facenf. uerj.br/v18n1/v18n1a17.pdf

7. Santos EA, Tavares DMS, Rodrigues LR, Dias FA, Ferreira PCS. Morbidades e qualidade de vida de idosos com diabetes mellitus residentes nas zonas rural e urbana. Rev Esc Enferm USP. 2013;47(2):393-400.
8. Leal LB, Moura IH, Carvalho RBN, Leal NTB, Silva $A Q$, Silva ARV. Qualidade de vida relacionada à saúde de pessoas com diabetes mellitus tipo 2. Rev Rene [Internet]. 2014 [acesso em 12 jun. 2016];15(4):67682. Disponível em: http://www.revistarene.ufc.br/ revista/index.php/revista/article/view/1684/pdf

9. Stival MM, Lima LR, Funghetto SS, Silva AO, Pinho DLM, Karnikowski MGO. Fatores associados à qualidade de vida de idosos que frequentam uma unidade de saúde do Distrito Federal. Rev Bras Geriatr Gerontol. 2014;17(2):395-405.

10. Frota SS, Guedes MVC, Lopes LV. Fatores relacionados à qualidade de vida de pacientes diabéticos. Rev Rene [Internet]. 2015 [acesso em 15 jun. 2016];16(5):63948. Disponível em: http://www.repositorio.ufc.br/ bitstream/riufc/14492/1/2015_art_ssfrota.pdf

11. Sousa MC, Dias FA, Nascimento JS, Tavares DMS. Correlation of quality of life with the knowledge and attitude of diabetic elderly. Invest Educ Enferm [Internet]. 2016 [acesso em 15 jun. 2017];34(1):180-8. Disponível em: http://www.scielo.org.co/pdf/iee/ v34n1/v34n1a20.pdf

12. Mata AR, Álvares J, Diniz LM, Ruberson M, Alvernaz BR, Guerra Júnior BA et al. Quality of life of patients with Diabetes Mellitus Types 1 and 2 from a referal health centre in Minas Gerais, Brazil. Expert Rev Clin Pharmacol [Internet]. 2016 [acesso em 10 abr. 2017]:1-13. Disponível em: http://www. tandfonline.com/doi/abs/10.1586/17512433.2016.1152 180 ?journalCode $=$ ierj20

13. WHOQOL Group. The WHO quality of life assessment (WHOQOL): Development and general psychometric properties. Soc Sci Med. 1998;46:1569-83.

14. Chibante CIP, Sabóia VM, Teixeira ER, Silva JLL. Qualidade de vida de pessoas com diabetes mellitus. Rev Baiana Enferm [Internet]. 2014 [acesso em 14 jun. 2016];28(3):235-43. Disponível em: https:// portalseer.ufba.br/index.php/enfermagem/article/ view/11909/8986 
15. Fleck MPA, Louzada S, Xavier M, Chachamovich E, Vieira G, Santos L, et al. Aplicação da versão em português do instrumento abreviado de avaliação da qualidade de vida "WHOQOL-bref". Rev Saúde Pública. 2000;34(2):178-83.

16. Fleck MPA, Chachamovich E, Trentini C. Development and validation of the Portuguese version of the WHOQOL-OLD module. Rev Saúde Pública. 2006;40(5):785-91.

17. Oliveira ERA, Gomes MJ, Paiva KM. Institucionalização e qualidade de vida de idosos da região Metropolitana de Vitória- ES. Rev Esc Enferm USP. 2011;15(3):518-23.

18. Franco Junior AJA, Heleno MGV, Lopes AP. Qualidade de vida e controle glicêmico do paciente portador de Diabetes Mellitus tipo 2. Rev Psicol Saúde [Internet]. 2013 [acesso em14 jun. 2016];5(2):102-8. Disponível em: http://pepsic. bvsalud.org/pdf/rpsaude/v5n2/v5n2a05.pdf

19. Tavares DMS, Dias FA. Capacidade funcional, morbidades e qualidade de vida de idosos. Texto \& Contexto Enferm [Internet]. 2012 [acesso em 10 jun. 2017];21(1):112-20. Disponível em: http://www.scielo. br/pdf/tce/v21n1/a13v21n1.pdf

20. Dahmer L, Oliveira TB, Kemper C, Sant'Ana AP, Melo GL, Avila JG. Avaliação da qualidade de vida de pacientes hipertensos e diabéticos. Rev Contexto \& Saúde [Internet]. 2015 [acesso em 13 abr 2017];15(28):419. Disponível em: https://www.revistas.unijui.edu.br/ index.php/contextoesaude/article/view/3211/3688

21. Nogueira MF, Magalhães LD, Maia AKF, Torquato IMB, Trigueiro JVS, Alves MSCF. Quality assessment of elderly living with diabetes mellitus. J Nurs UFPE On Line [Internet]. 2015 [ acesso em 15 jun. 2016];9(Suppl. 6):8688-97. Disponível em: http:// www.revista.ufpe.br/revistaenfermagem/index.php/ revista/article/view/7498/pdf_8251

22. Lame AN, Olsen JA. Yes, health is important, but as much for its importance via social life: the direct and indirect effects of health on subjective well-being in chronically ill individuals. Health Econ [Internet]. 2017 [acesso em 15 jun 2017];114. Disponível em: https://www.researchgate.net/ publication/318049784_Yes_health_is_important_ but_as_much_for_its_importance_via_social_life_ The_direct_and_indirect_effects_of_health_on_ subjective_well-being_in_chronically_ill_individuals
23. Riaz M, Rehman RA, Hakeem R, Shahen F. Health related quality of life in patients with diabetes using SF-12 questionnaire. J Diabetol [Internet]. 2013 [acesso em 12 abr. 2016];2(1):1-7. Disponível em: https://www.researchgate.net/ publication/249008506_Health_related_quality_ of_life_in_patients_with_diabetes_using_SF-12_ questionnaire

24. Matias COF, Matias COF, Alencar BR. Qualidade de vida em idosos portadores de Diabetes Mellitus Tipo 2 atendidos em Unidades Básicas de Saúde de Montes Claros/MG. Rev Bras Qual Vida [Internet]. 2016 [acesso em 15 jun. 2017];8(2):119-29. Disponível em: https://periodicos.utfpr.edu.br/rbqv/article/ view/3841/2782

25. D’Amato C, Morganti R, Greco C, Gennaro FD, Cacciotti L, Longo S, et al. Diabetic peripheral neuropathic pain is a stronger predictor of depression than other diabetic complications and comorbidities. Diabetes Vasc Dis Res [Internet]. 2016[acesso em 15 jun. 2017];13(6):418-28.

Disponível em: http://journals.sagepub.com/doi/ pdf/10.1177/1479164116653240

26. De Oliveira JEP, Vencio S, organizadores. Diretrizes da Sociedade Brasileira De Diabetes (2015-2016) [Internet]. São Paulo: A.C. Farmacêutica; 2016 [acesso em 15 jun. 2017]; Disponível em: http:// www.diabetes.org.br/profissionais/images/docs/ DIRETRIZES-SBD-2015-2016.pdf

27. American Diabetes Association. Diabetes Guidelines 2016. Summary Recommendations from NDEI [Internet]. 2016. [acesso em 15 jun. 2017]; Disponível em: http://www.ndei.org/ADA-diabetesmanagement-guidelines-diagnosis-A1C-testing.aspx

28. Kraychete DC. Dor cronica persistente [Internet]. [sem local]: Cristália; 2016 [acesso em 15 jun. 2017]. Disponível em: http://www.sbed.org.br/sites/ arquivos/downloads/fasc_cro_persist.pdf

29. Rodrigues FFL, Santos MA, Teixeira CRS, Gonela JT, Zanetti ML. Relação entre conhecimento, atitude, escolaridade e tempo de doença em indivíduos com diabetes mellitus. Acta Paul Enferm [Internet]. 2012 [acesso em 15 jin. 2017];25(2):28490. Disponível em: http://dx.doi.org/10.1590/S010321002012000200020 